\title{
下顎前柬部排列位置の変化が発音に及ぼす影響
}

\author{
九州䨑科大学大学院㐘学研究科歯科補経学第 1 専攻（指導：豊田静夫教授） \\ 桃谷 泰 蔵 \\ 昭和 62 年 10 月 23 日受付
}

\section{Effect of the Changes in the Artificial Tooth Position in the Lower Anterior Region on Articulation \\ Taizou Momotani}

1st Department of Prosthetic Dentistry (Director: Prof. Shizuo Toyoda)

Kyushu Dental College, Kitakyushu, Japan

The oral cavity with such articulatory organs as the lips, tongue, uvula, and soft palate which are very versatile in mobility plays an important role of articulatory function in producing various sounds by changing their forms. When many teeth are lost by surgery or periodontosis, it is well known by experience that the articulatory function of the oral cavity is greatly impaired and speech impediment is induced.

In practice in prosthodontics, therefore, it is very important to restore the articulatory function, as well as esthetic and occlusion, by carrying out a prosthetic treatment at the region with a tooth-loss. In view of the articulatory function, it is important to examine the relation between artificial tooth position and articulation.

Four types of experimental dentures with over bite and over jet varied were therefore prepared for the cases of a tooth-loss at the lower anterior region. Five syllables of "S" followed by a vowel in Japanese ( $\mathrm{Sa}, \mathrm{Si}, \mathrm{Su}, \mathrm{Se}, \mathrm{So}$ ) were designated as the target syllables and analyses of " $S$ " position on Mandibular Kinesiograph and of the voice on a sound spectrograph were made. Then, the effect of the changes in the artificial tooth position in the lower anterior tooth region on articulation was examined in detail.

The results were as follows:

1. With the standard-type experimental denture with over bite at $2 \mathrm{~mm}$ and over jet at $2 \mathrm{~mm}$, no positional changes in the anteroposterior " $\mathrm{S}$ " position were found in any of the "S" syllables.

2. The up-down "S" positions differed among the target syllables. The positions for "So" showed the greatest difference in comparison with other syllables.

3. The effect of increase in over jet on the anteroposterior " $S$ " position was greater in comparison with the up-down " $S$ " position, and the anteroposterior " $S$ " position tended to be displaced forward. However, with the experimental denture with over bite at $4 \mathrm{~mm}$ and over jet at $6 \mathrm{~mm}$, the tendency toward forward displacement of the anteroposterior "S" position decreased. 
4. The effect of increase in over jet on the up-down "S" position was rather small, and no fixed patterns were seen in the displacement direction of the up-down " $S$ " position .

5. The consonant duration differed among the target syllables. It was comparatively long for "Si" and "Su" and was the shortest for "Sa".

6. The effect of the artificial tooth position in the lower anterior region on the consonant duration was small.

7. The average amplitude differed among the target syllables. It was comparatively large for "Si" and "Su" and was the smallest for "Sa".

8. The effect of increase in over jet on the average amplitude was very marked. Although the average amplitude showed a decreasing tendency, the experimental denture with over bite at $4 \mathrm{~mm}$ and over jet at $6 \mathrm{~mm}$, showed a decline in the rate of decrease.

9. Analyses of frequency showed that the energy level tended to decline in the hlgh frequency range form $4,500 \sim 5,000 \mathrm{~Hz}$ to $9,500 \sim 10,000 \mathrm{~Hz}$ for all target syllables of " $\mathrm{S}$ " with an increase in over jet. However with the experimental denture with over bite at $4 \mathrm{~mm}$ and over jet at $6 \mathrm{~mm}$, the declining tendency of energy level decreased.

\section{Key words : Full denture/Speech/Pronunciation/Sound spectrograph}

\section{緒言}

語音は，㗋頭，咽頭，鼻腔，口腔の総合的な協調作業 そよって形成される。乙れらの調音器官のうち口唇, 舌，口蓋垂，軟口蓋などの運動性に富む調音体をもつ口 腔は，発音時にその形態を変化させ，さまざまな語音を 作りだすうえで，発音機能に重要な役割を果している。 しかし外科的処置や菌周疾患により多数の歯牙が欠損す ると口腔の発音機能は著しい障害を受け，発音障害が引 き起てされることは経験的に広く知られている，そてで 禣緅臨床において，歯牙が欠損した部位に補経処置を施 し審美，咬合とともに発音機能の回復をはかることは非 常に重要な問題である。しかし一方では, 補経物が各個 人特有の複雑な調音運動と調和しない場合は各種の発音 障害を引き起こすことも事実である。

従来より義歯の発音障害に関する報告は数多くみうけ られ，被験者の自覚的障害の検查 ${ }^{1}{ }^{\prime}$ ，聴覚を利用した発 音明瞭度の検榃 ${ }^{2-101}$ ，パラトグラフ, リンゴグラフ, $\mathrm{X}$ 線による発音時の舌の動態の観察 5 , 8,11-18) マンディブ ラーキネジオグラフ，X線映画法による $\mathrm{S}$ 発音位の観察 $12,14,15,19-25)$, オッシログラフ, サウンドスペクトロ グラフによる音声スペクトルの分析などの方法 ${ }^{3,4,19-}$ 24,26-36) により, バラタルバー, 咬合高径, 口蓋部の 厚さや形態, 人工歯の排列位置などが発音機能に及ぼす
影響について詳細な検討がくわえられている．特に摩擦 音などの前歯部付近に調盗点をもつ語音においては前歯 部の排列位置が最も重要であり，それが習慣的な発音時 の機能運動と調和しない場合は, 種々の発音障害をもた らすてとになる．そこで人工蒾の排列位置は発音機能 に值接影響を及ぼす重要な因子であることに着目し， Silverman $(1951,1956)^{37,38)}$, Pound (1966. 1971) 39，40) らは $\mathrm{S}$ 発音位を利用して下顎前床を排列し，発音 機能に調和した義歯を作製する方法を提唱した。しかし 上䫑については主として番美性が重要視され顔貌と調和 する位置に排列しなければならず，発音機能を最優先さ せて排列するというわけにはいかない，したがって発音 機能において下顎前歯部の排列位置の果たす役割は大き く，下頂前雨部の排列位置と発音との関係を検討するて とは非常に重要であり，発音改善のための一つの指標と なりうるはずである。そてで著者は下顎前歯部を含む欠 損症例に対してオーバージェット，オーバーバイトを変 化させた 4 種の実験用義歯を作製し，マンディブラーキ ネジオグラフによる S 発音位の分析およびサウンドスぺ クトログラフによる音声の分析を行い，下顎前蒾部排列 位置の変化が発音に及ぼす影響を詳細に検討したとて ろ，興味ある知見を得たので報告する。 


\section{実 験 方 法}

下顎前蒾部の排列位置が発音に及ぼす影響を検討する ため，下顎前歯部を含む久損症例に対し，被蓋の異なる 4 種の実験用義柬を作製し, サ行音発音時の切茵点の位 置をマイオトロニクス社製マンディブラーキネジオグラ フ $\mathrm{K} 5$ 型（以下 $\mathrm{M} \cdot \mathbf{K} \cdot \mathbf{G}$. と略す）で記録するととも に，同時に録音した被験音をりオン社製サウンドスペク トログラフ S G-09で分析した。

\section{I . 被験者}

被験者は九州菌科大学付属病院に義歯作製を希望して 来院した患者のち，下顎前曾を含む欠損症例で，局部床 義歯を新しく作製した年齢38～72歳，平均52歳の男性 12 名, 女性 8 名, 訫 20 名であった。 なお，被験者は，以下 の基準に従って選択した。

1）下顎前霆が連続 5 歯以上久損しているもの.

2）下顎臼蒾部に骨植堅固な天然歯が残存しているも の.

3) 維持, 安定が良好な下顎局部床義摤を 1 力月以上 装着しているもの。

4) 上顎は健全な天然崡であるか，維持安定が良好な 局部休義歯を装着しているもの.

5) とくに方言がなく，自覚的，他覚的発音障害がな いもの.

6) 顎形態, 口腔周辺の筋, 神経および顎関節に異常 がないもの。

\section{II ．実験用義歯}

実験用義歯作製のために，下簤についてはポリサルフ フイドラバー印象材, レギュラータイプで, また対合料 である上觀はアルジート印象材で印象採得し，咬合採 得後，平均值付着板を使用して上下顎模型を坪根式咬合 器に付着した．つぎにトレー用レジンで作製した基礎休 の維持安定を増強するため常温重合型レジンでりライニ ングを行った。前蒾部を除く欠損部位は常温重合型レジ ンを用いて人工蒾および床研磨面を筆積み法で形成し， 形態修正を行った，さらに，口腔内で可及的に動摇しな いように歯部に強固な維持装置を付与した。なおこの 義荬の唇側床研磨面の下部には， $\mathrm{S}$ 発音位を測定するた め $\mathbf{M} \cdot \mathbf{K} \cdot \mathbf{G} \cdot$ ・ マグネットを下唇の動きを阻害しないよ うに完全に埋め込んだ，実験用義蒾の前菡相当部には， 被蓋条件が異なる 4 種類の義柬を想定して，オーバーバ イト $2 \mathrm{~mm} ・$ オーバージェット $2 \mathrm{~mm}$, オーバーバイト $2 \mathrm{~mm} \cdot$ オーバージェット $4 \mathrm{~mm}$, オーバーバイト $2 \mathrm{~mm}$ ・オーバージェット $6 \mathrm{~mm}$, およびオーバーバィト $4 \mathrm{~mm}$

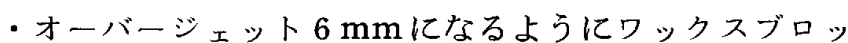
クを築盛した。.以後，乙れら義柬を順にD $(2,2), \mathrm{D}(2$, 4), $\mathrm{D}(2,6), \mathrm{D}(4,6)$ と呼ぶ(図 1 ).

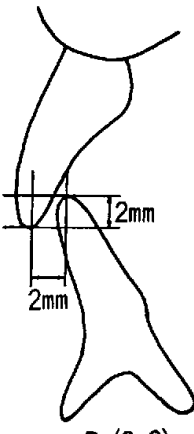

$\mathrm{D}(2,2)$

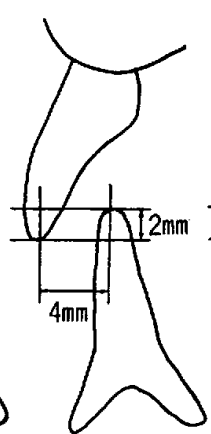

$D(2,4)$

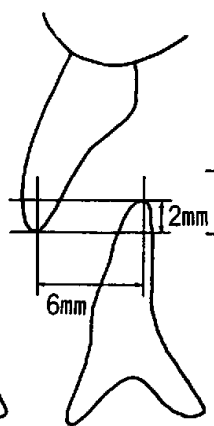

$D(2,6)$

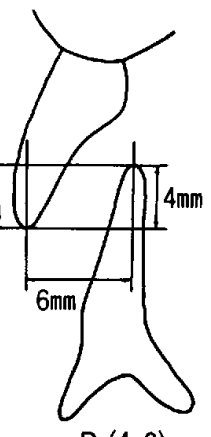

D $(4,6)$
図 1 実験用義䔥の被蓋関係

\section{III. 被験語ならびに録音庁法}

被験語としては前雬の排列位置と関連の深いサ行 5 音 を用い，サシスセソを1サイクルとし，被験者にそれぞ れの義歯を装着し 10 回練習させた後, D $(2,2), \mathrm{D}(2$, 4), $\mathrm{D}(2,6)$ の順に日常会話程度の速さ, 大きさで 5 回 づつ連続して発音させ録音した.ただし，10人の被験者 においては，乙の実験の後 D $(4,6)$ 義歯を装着させて同 様の実験を行った．録音は，雑音の入らない静かな室内 で，呼気の影響を防ぐため，患者の口と指向性のマイク ロホン (アイワ社製 DM-H 5 ) との距離を $30 \mathrm{~cm}$ に保つ ように注意して行った。なおテープレコーダーはアカイ 社製 C S - MO $1 \mathrm{~A}$, 録音テープはソニーH F - P R O を使用した。

N. 分析方法ならびに分析項目

\section{A. S 発音位の分析}

$\mathrm{S}$ 発音位の測定には下顎運動の三次元測定装置である $\mathbf{M} \cdot \mathbf{K} \cdot \mathbf{G}$.を使用した。まず実験用義崡を被験者に装着 させ, 中心咬合位で咬合させ, 通法に従いセンサーアレ イを装着し, 調整した後, 下顎の調音運動を $\mathbf{M} \cdot \mathbf{K} \cdot \mathbf{G}$. のブラウン管上に表示した。また下顎の動きを明確にと らえるため，M．K．G．に理化電気社製 2 ペンレコーダ -R202を接続し, 調音運動の上下成分, 前後成分を掃 引記録した。なお，下顎は $\mathrm{S}$ 発音位時にも連続的に運動 しているが, Silverman $(1951,1956)^{37,38) の ~ c l o s e s t ~}$ speaking space の定義に従って，下嶺が中心咬合位に 最も接近した任置を $\mathrm{S}$ 発音位とし，中心咬合位に対する 位置を上下成分ならびに前後成分にわけて測定した。

B . 音声分析

音声分析には夙波数分析装置であるサウンドスペクト 
ログラフを使用した。サウンドスペクトログラフは過渡 的な音声信号を時間，周波数，レベル（エネルギーの強 弱) の三次元で分析し，分析結果をパターン，セクショ ン, アンプリテュードディスプレィ，カンターディスプ レイの 4 種類のサウンドスペクトログラムで表すととが できる. 本研究では, 被験語に前雨部の排列位置と関係 の深いサ行音を用いたが，特にその影響を受けやすい子 音部注目し，パターン分析より子音継続時間を，アン プリテュードディスプレイ分析より音圧エネルギーを， セクション分析より各周波数成分のレベルを測定した. 設定した周波数レジンは 0 から $10,000 \mathrm{~Hz}$ ，選択したフ ィルターは300 Hz の広帯域フィルター, 録音時間は 2.4 秒とした。また，録音した被験音の再生レベルは，レベ ルメータの針が - $3 \mathrm{~dB}$ になるように調整し，オーバー ロードによる音声の歪を避けた．

\section{1. 子音継続時間}

子音継続時間の測定にはパターン分析により得られた サウンドスペクトログラムを用いた，子音継続時間はサ ウンドスペクトログラム上における先行子音の起始部か ら後続母音の第一フォルマント起始部までとして, 子音 と母音の移行部を含めて測定した。

\section{2. 平均振幅}

音圧エネルギーの指標である平均振幅の測定には，ア ンプリテュードディスプレイ法により得られたサウンド スペクトログラムを使用した。アンプリテュードディス プレイ曲線に扔いて，子音中央部の最高值を子音のエネ ルギーレベル，後続母音中央部の最高值を母音のエネル ギーレベルとし，母音のエネルギーレベルに対する子音 のエネルギーレベルを百分率で求めた.

3. 周波数分析
周波数分析にはセクション分析によるサウンドスペク トログラムを用いた。 あらかじめパターン分析の結果よ り決定した各被験音の子音中央部の時刻をサウンドスペ クトログラフにエントリーし，0 から $10,000 \mathrm{~Hz}$ まで500 $\mathrm{Hz}$ ごとに各周波数成分におけるそれぞれのエネルギー レベルを測定した。

\section{実 験 結 果}

I. S 発音位の分析結果

A. 上下的 S 発音位

各実験用義雨の上下的 S 発音位（中心咬合位を基準と する $\mathrm{S}$ 発音位の上下成分) の平均值と標準偏差を被験語 でとに求め表 1 亿示した。 $\mathbf{D}(2,2)$ において，上下的 $\mathrm{S}$

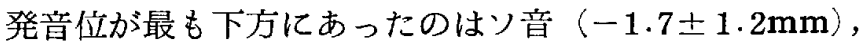
最も上方にあったのはセ音 $(-0.9 \pm 0.8 \mathrm{~mm})$ であった。 $\mathrm{D}(2,4)$ では，最も下方にあったのはセ音 $(-1.7 \pm 1.4$ $\mathrm{mm})$, 最も上方にあったのはセ音 $(-0.9 \pm 0.9 \mathrm{~mm})$ で あった， $\mathrm{D}(2,6)$ では, 最も下方にあったのはソ音(一 $1.6 \pm 1.3 \mathrm{~mm})$, 最も上方にあったのはセ音 $(-0.8 \pm$ $0.7 \mathrm{~mm})$ であった．また D $(4,6)$ では，最も下方にあ ったのはり音 $(-1.3 \pm 0.9 \mathrm{~mm})$, 最も上方にあったの はセ音 $(-0.8 \pm 0.7 \mathrm{~mm})$ であった。どの実験用義歯に おいても上下的 $S$ 発音位は，ソ音が最も下方にあり，七 音が最も上方にあった。またサ行 5 音の上下的 $S$ 発音位 の平均と標準偏差を各実験用義雪でとに比較すると，D

$(2,2)$ では $-1.2 \pm 1.1 \mathrm{~mm}, \mathrm{D}(2,4)$ では $-1.2 \pm 1.2$ $\mathrm{mm}, \mathrm{D}(2,6)$ では一 $1.1 \pm 1.1 \mathrm{~mm}, \mathrm{D}(4,6)$ では一 1.1 上0.9mmであり，どの実験用義茵に扔ても上下的 $\mathrm{S}$ 発音位の平均值はほほ同じ值を示した。 $\mathrm{D}(2,2)$ を基準 とし D $(2,2) \cdot \mathrm{D}(2,4)$ 間, $\mathrm{D}(2,2) \cdot \mathrm{D}(2,6)$ 間, D

表 1 上下的 $\mathrm{S}$ 発 音 位

\begin{tabular}{|c|c|c|c|c|c|c|}
\hline 実験用義雷 被験語 & サ & シ & z & セ & ソ & 平均値 \\
\hline \multirow{2}{*}{$\mathbf{D}(2,2)$} & -1.2 & -1.2 & -1.1 & -0.9 & -1.7 & -1.2 \\
\hline & 1.1 & 1.0 & 0.9 & 0.8 & 1.2 & 1.1 \\
\hline \multirow{2}{*}{$\mathrm{D}(2,4)$} & -1.3 & -1.2 & -1.1 & -0.9 & -1.7 & -1.2 \\
\hline & 1.3 & 1.0 & 1.0 & 0.9 & 1.4 & 1.2 \\
\hline \multirow{2}{*}{$\mathrm{D}(2,6)$} & -1.2 & -1.1 & -1.0 & -0.8 & -1.6 & -1.1 \\
\hline & 1.2 & 0.9 & 0.9 & 0.7 & 1.3 & 1.1 \\
\hline \multirow{2}{*}{$\mathrm{D}(4,6) \begin{array}{l}\text { 平均 值 } \\
\text { 標準偏差 }\end{array}$} & -1.1 & -1.1 & -1.1 & -0.8 & -1.3 & -1.1 \\
\hline & 0.9 & 0.9 & 0.9 & 0.7 & 0.9 & 0.9 \\
\hline
\end{tabular}

一は中心咬合位より下方にあることを示す。

(単位 $\mathrm{mm}$ ) 
$(2,2) \cdot \mathrm{D}(4,6)$ 間において上下的 S 発音位に関する平 均值の差の検定を行い，有意差があった被験語数を被験 語ごとに表 2 に示した。どの奏験用義雷の対応関係にお いても有意差があった被験語数は，被験語間で差は小さ くほほ同じであった，有意差があった被験語数の合計を 全被験語数に対する割合として求めると，D $(2,2) \cdot \mathrm{D}$ $(2,4)$ 間で $14 \%, \mathrm{D}(2,2) \cdot \mathrm{D}(2,6)$ 間で $38 \%$ であり, オーバージェットの増加にともない, それが上下的 $\mathrm{S}$ 発 音位に及ぼす影響も増加した。また $\mathrm{D}(2,2) \cdot \mathrm{D}(4,6)$ 間で有意差があった被験語数の割合は $50 \%$ あり，D $(2,2) \cdot \mathrm{D}(2,6)$ 間と比較するとその割合はやや増加し た。

各実験用義米間における上下的 $\mathrm{S}$ 発音位の平均值の差 の検定結果より, 有意差があった被験語数を被験者ごと に求め表 3 亿示した。 $\mathrm{D}(2,2) \cdot \mathrm{D}(2,4)$ 間ではどの被 験者においても有意差があった被験語数は少なかった。

$\mathrm{D}(2,2) \cdot \mathrm{D}(2,6)$ 間および $\mathrm{D}(2,2) \cdot \mathrm{D}(4,6)$ 問では有 意差があった被験語数は増加したが，被験者間のばらつ きが大きく被験者間の差も大きかった。

$B$. 前後的 $S$ 発音位
表 2 各実験用義荗間の上下的 $\mathrm{S}$ 発音位の分析結果 (被験語別)

\begin{tabular}{|c|c|c|c|c|c|c|c|}
\hline 対応 被験語 & サ & シ & ス & セ & ソ & 被験語数 & 割合 $(\%)$ \\
\hline$\frac{\mathrm{D}(2,2) \sim}{\mathrm{D}(2,4)}$ & 2 & 3 & 2 & 3 & 4 & 100 & 14 \\
\hline $\mathrm{D}(2,2) \sim(2,6)$ & 8 & 7 & 8 & 7 & 8 & 100 & 38 \\
\hline $\begin{array}{c}\mathrm{D}(2,2) \sim \\
\mathrm{D}(4,6)\end{array}$ & 6 & 5 & 5 & 5 & 4 & 50 & 50 \\
\hline
\end{tabular}

数字は平均值の差の検定（危険率 $5 \%$ ）より有意差 があった被験語数を示す。

各実験用義歯の前後的 S 発音位（中心咬合位を基準と する S 発音位の前後成分) の平均值と䅺準偏差を被験語 ごとに求め表 4 に示した．どの実験用義霜においても各 被験語はほほ同じ值であり，被験語間の差は小さかっ た. サ行 5 音の前後的 $\mathrm{S}$ 発音位の平均值と標準偏差を実 験用義菌ごとに比較すると， $\mathrm{D}(2,2)$ では $-0.1 \pm 0.5$ $\mathrm{mm}, \mathrm{D}(2,4)$ では $0.1 \pm 0.5 \mathrm{~mm}, \mathrm{D}(2,6)$ では $0.3 \pm$ $0.6 \mathrm{~mm}, \mathrm{D}(4,6)$ では $-0.1 \pm 0.5 \mathrm{~mm}$ であった。 $\mathrm{D}(2$ ，

表 3 各咨験用義歯間の上下的 $\mathrm{S}$ 発音位の分析結果（被験者別）

\begin{tabular}{l|ccccccccccccccccccccc}
\hline 対 応 & 被験者 & A & B & C & D & E & F & G & H & I & J & K & L & M & N & O & P & Q & R & S & T \\
\hline $\mathrm{D}(2,2) \sim \mathrm{D}(2,4)$ & 0 & 2 & 2 & 0 & 1 & 0 & 0 & 0 & 0 & 0 & 0 & 0 & 2 & 0 & 1 & 3 & 1 & 0 & 2 & 0 \\
\hline $\mathrm{D}(2,2) \sim \mathrm{D}(2,6)$ & 0 & 5 & 1 & 0 & 3 & 0 & 0 & 0 & 0 & 5 & 5 & 5 & 1 & 0 & 2 & 2 & 3 & 0 & 5 & 1 \\
\hline $\mathrm{D}(2,2) \sim \mathrm{D}(4,6)$ & 2 & 5 & 5 & 1 & 0 & 1 & 4 & 1 & 1 & 5 & - & - & - & - & - & - & - & - & - & - \\
\hline
\end{tabular}

数字は平均值の差の検定（危険率 $5 \%$ ）より有意差があった被験語数を示す.

表 4 前後的 $\mathrm{S}$ 発音位

\begin{tabular}{|c|c|c|c|c|c|c|}
\hline 実験用義畨 被験語 & サ & シ & ス & 七 & ソ & 平均値 \\
\hline \multirow{2}{*}{$\mathrm{D}(2,2)$} & 0.0 & -0.1 & -0.1 & 0.0 & -0.1 & -0.1 \\
\hline & 0.5 & 0.5 & 0.5 & 0.4 & 0.6 & 0.5 \\
\hline \multirow{2}{*}{$\mathrm{D}(2,4)$} & 0.1 & 0.0 & 0.1 & 0.1 & 0.1 & 0.1 \\
\hline & 0.5 & 0.5 & 0.5 & 0.5 & 0.6 & 0.5 \\
\hline \multirow{2}{*}{$\mathrm{D}(2,6)$} & 0.3 & 0.3 & 0.3 & 0.3 & 0.3 & 0.3 \\
\hline & 0.6 & 0.6 & 0.5 & 0.5 & 0.6 & 0.6 \\
\hline \multirow{2}{*}{$\mathrm{D}(4,6) \begin{array}{l}\text { 平均 値 } \\
\text { 標準偏差 }\end{array}$} & -0.1 & -0.1 & -0.1 & -0.1 & -0.2 & - 0.1 \\
\hline & 0.5 & 0.5 & 0.5 & 0.5 & 0.7 & 0.5 \\
\hline
\end{tabular}

十は前方にあることを示す．

(単位 $\mathbf{m m}$ )

一は後方にあることを示す。 
表 5 各実験用義菌間の前後的 $S$ 発音位の分析結果 （被験語別）

\begin{tabular}{|c|c|c|c|c|c|c|c|}
\hline 対応 被験語 & サ & シ & ス & セ & ソ & 被験語数 & 姪合 $(\%)$ \\
\hline $\begin{array}{l}\mathrm{D}(2,2) \sim \\
\quad \mathrm{D}(2,4)\end{array}$ & 7 & 6 & 6 & 6 & 9 & 100 & 34 \\
\hline $\begin{array}{l}\mathrm{D}(2,2) \sim \\
\mathrm{D}(2,6)\end{array}$ & 15 & 14 & 19 & 16 & 17 & 100 & 81 \\
\hline$\frac{\mathrm{D}(2,2) \sim}{\mathrm{D}(4,6)}$ & 5 & 7 & 6 & 6 & 5 & 50 & 58 \\
\hline
\end{tabular}

数字は平均値の差の検定（危険率 $5 \%$ ）より有意差 があった被験語数を示す。

2)， $\mathrm{D}(2,4) ， \mathrm{D}(4,6)$ の前後的 $\mathrm{S}$ 発音位はほぼ同じ位 置にあり, $\mathrm{D}(2,6)$ の前後的発音位はやや前方に位置す る傾向を示した。つぎに $\mathrm{D}(2,2)$ を基準とし， $\mathrm{D}(2,2)$ ・ $\mathrm{D}(2,4)$ 間, $\mathrm{D}(2,2) \cdot \mathrm{D}(2,6)$ 間, $\mathrm{D}(2,2) \cdot \mathrm{D}(4,6)$ 間において前後的 S 発音位に関する平均值の差の検定を 行い，有意差があった被験語数を被験語でとに表 5 亿示 した．どの実験用義䍘の対応関係においても有意差があ った被験語数は, 被験語間で差は小さくほぼ同じであっ た。有意差があった被験語数の合計を全被験語数に対す
る割合として求めると， $\mathrm{D}(2,2) \cdot \mathrm{D}(2,4)$ 間で $34 \%$, $\mathrm{D}(2,2) \cdot \mathrm{D}(2,6)$ 間で $81 \%, \mathrm{D}(2,2) \cdot \mathrm{D}(4,6)$ 間で58 \%であり，オーバージェットの増加にともないそれが前 後的 $\mathrm{S}$ 発音位に及ぼす影響も増加した。ただし， $\mathrm{D}(2$ ， 2)・D $(4,6)$ 間では, 有意差があった被験語数の割合は 減少しており，オーバージェットを $4 \mathrm{~mm}$ 増加させオー バーバイトを $2 \mathrm{~mm}$ 堌加させた場合は, 被蓋度が前後的 $\mathrm{S}$ 発音位に及ぼす影響は減少した。

各実験用義歯間における前後的 $\mathrm{S}$ 発音位の平均值の差 の検定結果より，有意差があった被験語数を被験者で とに求め表 6 亿示した。 $\mathrm{D}(2,2) \cdot \mathrm{D}(2,4)$ 間および $\mathrm{D}$ $(2,2) \cdot \mathrm{D}(4,6)$ 間では有意差があった被験語数は被験 者間でばらつきが大きく，被験者間の差が大きかった。 $\mathrm{D}(2,2) \cdot \mathrm{D}(2,6)$ 間ではサ行 5 音全てに有意差があっ た被験者は 12 人， 5 音中 4 音に有意差があった被験者は 2 人， 5 音中 3 音に有意差があった被験者は 2 人であ り，ほとんどの被験者にオーバージェットが増加した影 響が認められた。

\section{II. 周波数分析結果}

\section{A. 子音継続時間}

各実験用義菌における各サ行音別の子音継続時間の平

表 6 各実験用義歯間の前後的 $\mathrm{S}$ 発音位の分析結果（被験者別）

\begin{tabular}{|c|c|c|c|c|c|c|c|c|c|c|c|c|c|c|c|c|c|c|c|c|}
\hline 対 応 被験者 & A & B & C & D & $\mathrm{E}$ & $\mathbf{F}$ & G & $\mathrm{H}$ & $\mathbf{I}$ & $\mathbf{J}$ & K & L & $\mathbf{M}$ & $\mathrm{N}$ & $\mathrm{O}$ & $\mathbf{P}$ & Q & & $\mathbf{S}$ & $\mathbf{T}$ \\
\hline $\mathrm{D}(2,2) \sim \mathrm{D}(2,4)$ & 5 & 0 & 1 & 1 & 1 & 0 & 1 & 0 & 2 & 5 & 1 & 5 & 0 & 0 & 4 & 5 & 0 & 2 & 0 & 1 \\
\hline $\mathrm{D}(2,2) \sim \mathrm{D}(2,6)$ & 5 & 2 & 5 & 2 & 4 & 5 & 3 & 5 & 3 & 5 & 5 & 5 & 5 & 2 & 5 & 5 & 4 & 5 & 1 & 5 \\
\hline $\mathrm{D}(2,2) \sim \mathrm{D}(4,6)$ & 3 & 1 & 1 & 5 & 1 & 5 & 4 & 4 & 0 & 5 & - & - & - & - & - & - & - & - & - & - \\
\hline
\end{tabular}

数字は平均値の差の検定（危険率 $5 \%$ ）より有意差があった被験語数を示す.

表 7 子音 継 続 時間

\begin{tabular}{|c|c|c|c|c|c|c|c|}
\hline 実験用義自 & 篓 被験語 & サ & シ & ス & セ & ソ & 平均値 \\
\hline \multirow{2}{*}{$\mathrm{D}(2,2)$} & \multirow{2}{*}{$\begin{array}{l}\text { 平均 值 } \\
\text { 標準偏差 }\end{array}$} & 124 & 145 & 142 & 140 & 138 & 138 \\
\hline & & 27 & 33 & 27 & 33 & 28 & 30 \\
\hline \multirow{2}{*}{$\mathrm{D}(2,4)$} & \multirow{2}{*}{$\begin{array}{l}\text { 平均值 } \\
\text { 標準偏差 }\end{array}$} & 124 & 145 & 144 & 141 & 139 & 139 \\
\hline & & 28 & 38 & 30 & 39 & 33 & 34 \\
\hline \multirow{2}{*}{$\mathrm{D}(2,6)$} & \multirow{2}{*}{$\begin{array}{l}\text { 平 均 值 } \\
\text { 標準偏差 }\end{array}$} & 125 & 145 & 142 & 141 & 139 & 138 \\
\hline & & 35 & 41 & 35 & 39 & 35 & 37 \\
\hline \multirow{2}{*}{$\mathrm{D}(4,6)$} & \multirow{2}{*}{$\begin{array}{l}\text { 平均 值 } \\
\text { 標準偏差 }\end{array}$} & 128 & 149 & 148 & 146 & 146 & 143 \\
\hline & & 33 & 38 & 37 & 44 & 37 & 39 \\
\hline
\end{tabular}

(単位 msec) 
均值と標準偏差を被験語ごとに求め表 7 に示した。D $(2,2)$ において，子音継続時間が最も長かったのはシ音

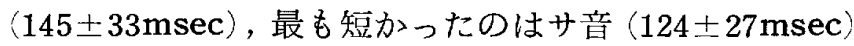
であった～ $\mathrm{D}(2,4)$ では，最も長かったのはシ音（145

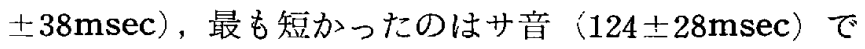
あった、 D (2,6) では, 最も長かったのはシ音（145士 $41 \mathrm{msec})$, 最も短かったのはサ音 $(125 \pm 35 \mathrm{msec})$ であ た。また D $(4,6)$ では，最も長かったのはシ音（149士

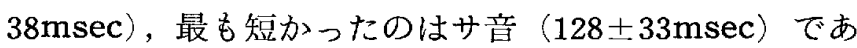
った，どの実験用義菌においても子音継続時間は, シ音 が最も長くサ音が最も短かった。またサ行 5 音の子音継 続時間の平均值と標準偏差を実験用義菡ごとに比較する

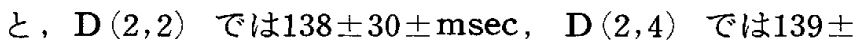
$34 \mathrm{msec}, \mathrm{D}(2,6)$ では $138 \pm 37 \mathrm{msec}$ であり, $\mathrm{D}(4,6)$ で

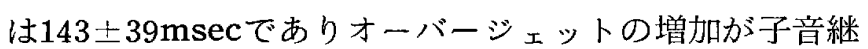
続時間に及ぼす影響はほとんど認められなかった。D $(2,2)$ を基準とし, $\mathrm{D}(2,2) \cdot \mathrm{D}(2,4)$ 間, $\mathrm{D}(2,2) \cdot \mathrm{D}$ $(2,6)$ 間, $\mathrm{D}(2,2) \cdot \mathrm{D}(4,6)$ 間において子音継続時間 に関する平均值の差の検定を行い，有意差があった被験 語数を被験語でとに求め表 8 亿示した。 どの実験用義茵 の対応関係においても有意差があった被験語数は, 被験 語間で差は小さくほぼ同じであった，有意差があった被

表 8 各実験用義菌間の子音継続時間の分析結果 (被験語別)

\begin{tabular}{|c|c|c|c|c|c|c|c|}
\hline 対応 被験語 & サ & シ & z & セ & ソ & 被験語数 & 割合 $(\%)$ \\
\hline $\begin{array}{l}\mathbf{D}(2,2) \widetilde{D}(2,4) \\
\quad\end{array}$ & 4 & 4 & 2 & 2 & 3 & 100 & 15 \\
\hline $\begin{array}{l}\mathrm{D}(2,2) \sim \\
\quad \mathbf{D}(2,6)\end{array}$ & 1 & 4 & 1 & 3 & 4 & 100 & 13 \\
\hline $\mathrm{D}(2,2) \sim(4,6)$ & 2 & 3 & 2 & 2 & 2 & 50 & 22 \\
\hline
\end{tabular}

数字は平均值の差の検定（危険率 $5 \%$ ）より有意差 があった被験語数を示す。
験語数の合計を全被験語数に刘する割合として求めると $\mathrm{D}(2,2) \cdot \mathrm{D}(2,4)$ 間で $15 \%, \mathrm{D}(2,2) \cdot \mathrm{D}(2,6)$ 間で13 $\%, \mathrm{D}(2,2) \cdot \mathrm{D}(4,6)$ 間で $22 \%$ あり, 被蓋度の変化 が子音継続時間に及ぼす影響はほとんど認められなかっ た。

各実験用義菌間における子音継続時間の平均值の差の 検定結果より，有意差があった被駼語数を被験者でとに 求め表 9 に示した。 ぞの実験用義歯の対応関係において も, $\mathrm{E} の$ 被験者を除けば被蓋度の変化が子音継続時間に 及ばす影響は小さかった。

\section{B . 平均振幅}

各実験用義歯における各サ行音別の平均振幅の平均値 と標準偏差を被験語ごとに求め表10に示した，D $(2,2)$ において，平均振幅が最も大きかったのはス音（108.3

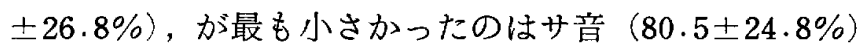
であったＤ D $(2,4)$ では，最も大きかったのはシ音 $(97.6$

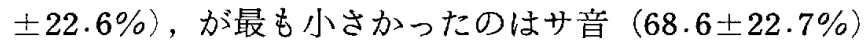
であった、 $\mathrm{D}(2,6)$ では，最も大きかったのはス音 $(82.4$ $\pm 18.1 \%) ，$ 最も小さかったのはサ音 $(58.2 \pm 20.1 \%)$ であった。また D (4,6) では，最も大きかったのはス音

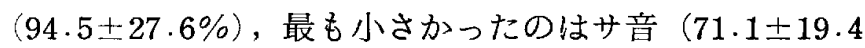
\%)であった。どの実験用義歯においても平均振幅は， シ音あるいはス音が大き值を示し，サ音が最も小さかっ た. またサ行 5 音の平均振幅の平均之標準偏差を実験用 義歯でとに比較すると，D $(2,2)$ では $95.2 \pm 29.0 \%, \mathrm{D}$ $(2,4)$ では $84.1 \pm 26.6 \%, \mathrm{D}(2,6)$ では72.0 $21.9 \%, \mathrm{D}$ $(4,6)$ では $84.0 \pm 24.3 \%$ であり， D $(2,2)$ を基準とする と, 平均振幅は $\mathrm{D}(2,4)$ では $11.1 \%, \mathrm{D}(2,6)$ では23.2 $\%, \mathrm{D}(4,6)$ では $11.2 \%$ 減少した.オーバージェットの 増加にともない平均振幅は減少したが，D $(4,6)$ で示す ようにオーバージェットを $4 \mathrm{~mm}$ 増加させオーバーバイ 卜を $2 \mathrm{~mm}$ 增加させた場合は, 平均振幅の减少率が低下 した.

$\mathrm{D}(2,2)$ を基準とし， $\mathrm{D}(2,2) \cdot \mathrm{D}(2,4)$ 間， $\mathrm{D}(2,2)$ - $\mathrm{D}(2,6)$ 間, $\mathrm{D}(2,2) \cdot \mathrm{D}(4,6)$ 間に扔いて平均振幅

表 9 各実験用義歯間の子音継続時間の分析結果（被験者別）

\begin{tabular}{c|ccccccccccccccccccccc}
\hline 対 応 & $\mathrm{A}$ & $\mathrm{B}$ & $\mathrm{C}$ & $\mathrm{D}$ & $\mathrm{E}$ & $\mathrm{F}$ & $\mathrm{G}$ & $\mathrm{H}$ & $\mathrm{I}$ & $\mathrm{J}$ & $\mathrm{K}$ & $\mathrm{L}$ & $\mathrm{M}$ & $\mathrm{N}$ & $\mathrm{O}$ & $\mathrm{P}$ & $\mathrm{Q}$ & $\mathrm{R}$ & $\mathrm{S}$ & $\mathrm{T}$ \\
\hline $\mathrm{D}(2,2) \sim \mathrm{D}(2,4)$ & 0 & 0 & 0 & 0 & 4 & 1 & 0 & 0 & 2 & 0 & 0 & 1 & 0 & 2 & 1 & 0 & 2 & 0 & 2 & 0 \\
\hline $\mathrm{D}(2,2) \sim \mathrm{D}(2,6)$ & 0 & 1 & 0 & 0 & 5 & 0 & 0 & 0 & 1 & 0 & 0 & 1 & 1 & 1 & 1 & 1 & 1 & 0 & 0 & 0 \\
\hline $\mathrm{D}(2,2) \sim \mathrm{D}(4,6)$ & 0 & 2 & 2 & 0 & 5 & 0 & 1 & 0 & 0 & 1 & - & - & - & - & - & - & - & - & - & - \\
\hline
\end{tabular}

数字は平均值の差の検定（危険率 $5 \%$ ）より有意差があった被験語数を示す. 
表10 平均振幅

\begin{tabular}{|c|c|c|c|c|c|c|c|}
\hline 実験用義苜 & 战 被験語 & サ & シ & ス & セ & ソ & 平均值 \\
\hline \multirow{2}{*}{$\mathrm{D}(2,2)$} & \multirow{2}{*}{$\begin{array}{l}\text { 平 均 值 } \\
\text { 標準偏差 }\end{array}$} & 80.5 & 104.2 & 108.3 & 95.3 & 87.5 & 95.2 \\
\hline & & 24.8 & 27.7 & 26.8 & 28.7 & 27.8 & 29.0 \\
\hline \multirow{2}{*}{$\mathrm{D}(2,4)$} & \multirow{2}{*}{$\begin{array}{l}\text { 平 均 值 } \\
\text { 標準偏差 }\end{array}$} & 68.6 & 97.6 & 93.1 & 82.6 & 78.4 & $84 \cdot 1$ \\
\hline & & 22.7 & 22.6 & 24.4 & 29.2 & 23.3 & 26.6 \\
\hline \multirow{2}{*}{$\mathrm{D}(2,6)$} & \multirow{2}{*}{$\begin{array}{l}\text { 平 均 值 } \\
\text { 標準偏差 }\end{array}$} & 58.2 & 81.1 & 82.4 & 71.4 & 66.9 & 72.0 \\
\hline & & 20.1 & 21.1 & $18 \cdot 1$ & 21.3 & 19.6 & 21.9 \\
\hline \multirow{2}{*}{$\mathrm{D}(4,6)$} & \multirow{2}{*}{$\begin{array}{l}\text { 平 均 值 } \\
\text { 標準偏差 }\end{array}$} & 71.1 & 92.8 & 94.5 & 83.5 & 78.0 & 84.0 \\
\hline & & 19.4 & 22.8 & 27.6 & 25.1 & 17.8 & 24.3 \\
\hline
\end{tabular}

表11 各実験用義歯間の平均振幅の分析結果 (被験語別)

\begin{tabular}{|c|c|c|c|c|c|c|c|}
\hline 対応 被験語 & サ & $シ$ & ス & 七 & ソ & 被験語数 & 割合 $(\%)$ \\
\hline $\begin{array}{l}\mathrm{D}(2,2) \sim \\
\quad \mathrm{D}(2,4)\end{array}$ & 10 & 6 & 14 & 10 & 10 & 100 & 50 \\
\hline$\frac{\mathrm{D}(2,2) \sim}{\mathrm{D}(2,6)}$ & 16 & 13 & 19 & 18 & 15 & 100 & 81 \\
\hline $\mathrm{D}(\underset{\mathrm{D}(4,2) \sim}{(4,6)}$ & 7 & 8 & 7 & 10 & 8 & 50 & 80 \\
\hline
\end{tabular}

数字は平均值の差の検定（危険率 $5 \%$ ）より有差意 があった被験語数を示す.

に関する平均値の差の検定を行い，有意差があった被験 語数を被験語ごとに求め表11亿示した， D $(2,2) \cdot \mathrm{D}(2$, 4）間，および $\mathrm{D}(2,2) \cdot \mathrm{D}(2,6)$ 間において，有意差方 あった被験語数はシ音で最も少なかったてとを除けば， ぞの実験用義菌の対応関係においても被験語間の差は小 さかった。 また有意差があった被験語数の合計を全被験 語数に対する割合として求めると $\mathrm{D}(2,2) \cdot \mathrm{D}(2,4)$ 間 で50\%，D $(2,2) \cdot \mathrm{D}(2,6)$ 間で $81 \%, \mathrm{D}(2,2) \cdot \mathrm{D}(4,6)$
間で $80 \%$ であり，オーバージェットの増加にともない， それが平均振幅に及ぼす影響も増加した。

各義霜間における平均振幅の平均值の差の検定結果よ り，有意差があった被験語数を被験者でとに求め表 12 に 示した. $\mathrm{D}(2,2) \cdot \mathrm{D}(2,4)$ 間では有意差があった被験 語数のばらつきが大きく，被験語間の差は大きかった。 $\mathrm{D}(2,2) \cdot \mathrm{D}(2,6)$ 間ではサ行 5 音中 5 音全てに有意差 があった被験者は 8 人， 5 音中 4 音に有意差があった被 験者は 6 人； 5 音中 3 音に有意差があった被験者は 5 人 であり，ほとんどの被験者にオーバージェットが増加し た影響が認められた。 $\mathrm{D}(2,2) \cdot \mathrm{D}(4,6)$ 間も，D(2,2) - D $(2,6)$ 間と同様な傾向を示し, ほとんどの被験者で 被蓋度が変化した影響が認められた。

C. 周波数分析

サ行 5 音の周波数分析の結果を順に図 2 から図 6 亿示 した。縦軸にエネルギーレベル（dB） を，横軸に周波 数（Hz）を表した. $\mathrm{D}(2,2)$ を基準とした場合， $\mathrm{D}(2,4)$ ではサ行 5 音全てにおいて，4,000 4,500Hzから 9, 500 〜 $10,000 \mathrm{~Hz}$ までの高周波数域でエネルギーレベルは減 少した。 $\mathrm{D}(2,6)$ でも，ほぼ同じ周波数域で行 5 音全 てにおいてエネルギーレベルは減少したが， $\mathrm{D}(2,4)$ と

表12各実験用義歯間の平均振幅の分析結果（被験者別）

\begin{tabular}{l|ccccccccccccccccccccc}
\hline 対 応 & 被験者 & $\mathrm{A}$ & $\mathrm{B}$ & $\mathrm{C}$ & $\mathrm{D}$ & $\mathrm{E}$ & $\mathrm{F}$ & $\mathrm{G}$ & $\mathrm{H}$ & $\mathrm{I}$ & $\mathrm{J}$ & $\mathrm{K}$ & $\mathrm{L}$ & $\mathrm{M}$ & $\mathrm{N}$ & $\mathrm{O}$ & $\mathbf{P}$ & $\mathrm{Q}$ & $\mathrm{R}$ & $\mathrm{S}$ & $\mathrm{T}$ \\
\hline $\mathrm{D}(2,2) \sim \mathrm{D}(2,4)$ & 5 & 2 & 2 & 3 & 2 & 1 & 0 & 3 & 0 & 5 & 2 & 1 & 4 & 4 & 2 & 3 & 4 & 1 & 1 & 5 \\
\hline $\mathrm{D}(2,2) \sim \mathrm{D}(2,6)$ & 5 & 3 & 5 & 3 & 4 & 4 & 2 & 5 & 5 & 5 & 3 & 4 & 3 & 4 & 3 & 5 & 4 & 5 & 4 & 5 \\
\hline $\mathrm{D}(2,2) \sim \mathrm{D}(4,6)$ & 4 & 4 & 4 & 3 & 5 & 5 & 3 & 5 & 2 & 5 & - & - & - & - & - & - & - & - & - & - \\
\hline
\end{tabular}

数字は平均值の差の検定（危険率 $5 \%$ ）より有意差があった被験語数を示す. 


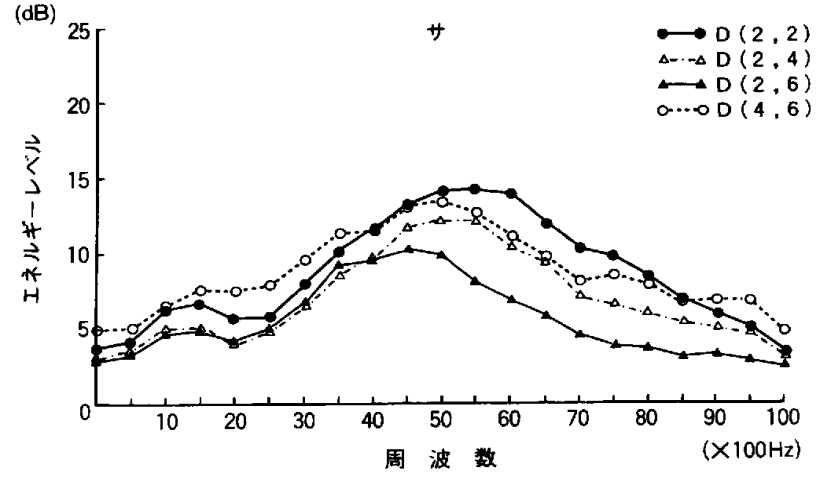

図 2 周 波 数 分 析

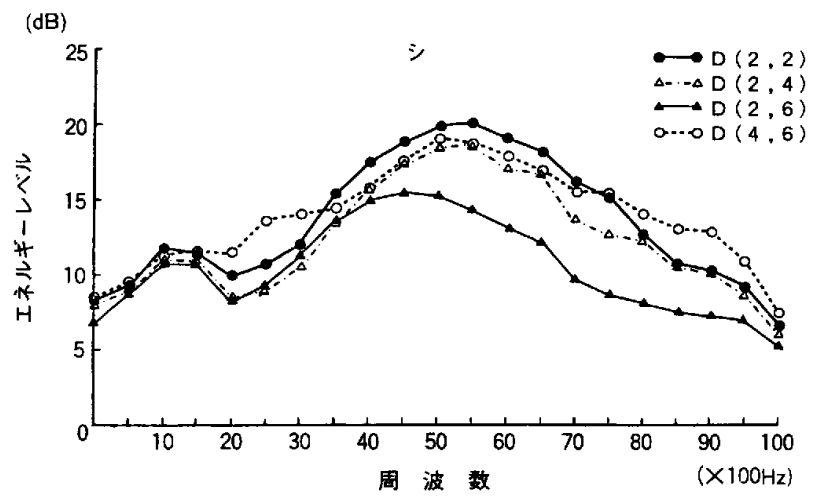

図 3 周 波 数 分 析

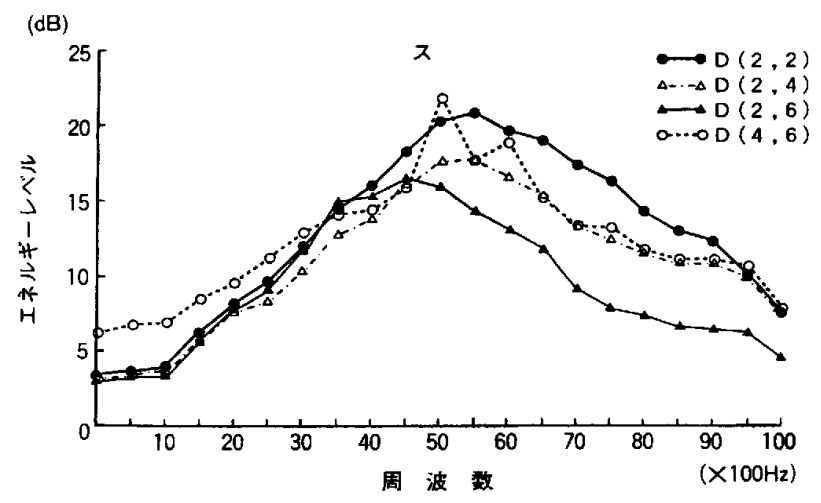

図4 周 波 数 分 析

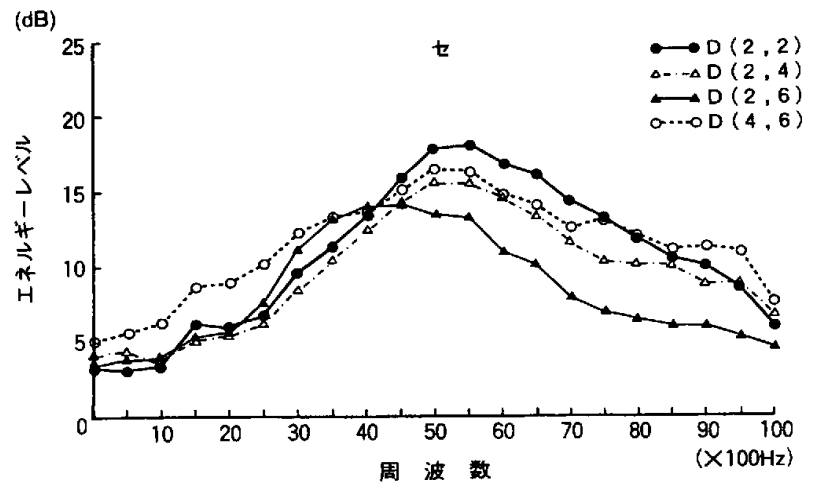

図 5 周 波 数 分 析

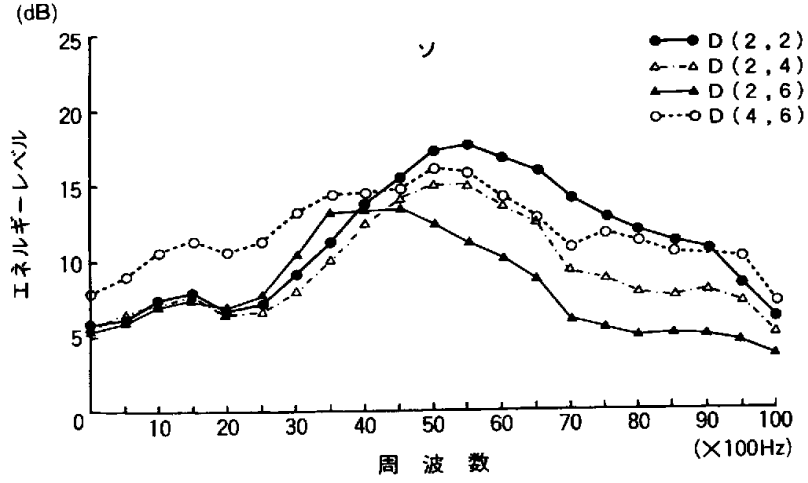

図6 周 波 数 分 析

比較すると減少傾向はさらに増加した，D(4,6) におい ても，ほぼ同じ周波数域でサ行 5 音全てにおいてエネル ギーレベルは減少したが, 減少傾向はD $(2,4)$ とほほ同 じ程度であった。

サ行 5 音の周波数分析の結果より，各語音別における 実験用義蒾ごとの強調点（エネルギーレベルが最大であ る周波数) の周波数を求め, 表 13 に示した. $\mathrm{D}(2,2)$ で

表13 強調点の周波数

\begin{tabular}{|c|c|c|c|c|c|c|}
\hline 実験用義菌 & サ & シ & ス & セ & ソ & 平均值 \\
\hline $\mathrm{D}(2,2)$ & 5500 & 5500 & 5500 & 5500 & 5500 & 5500 \\
\hline $\mathrm{D}(2,4)$ & 5000 & 5500 & 5500 & 5000 & 5000 & 5200 \\
\hline $\mathrm{D}(2,6)$ & 4500 & 4500 & 4500 & 4500 & 4500 & 4500 \\
\hline $\mathrm{D}(4,6)$ & 5000 & 5000 & 5000 & 5000 & 5000 & 5000 \\
\hline
\end{tabular}

は強調点の周波数はサ行 5 音全てが $5,500 \mathrm{~Hz}$ で, D $(2,4)$ では最高 $5,500 \mathrm{~Hz}$ ，最低 $5,000 \mathrm{~Hz}, \mathrm{D}(2,6)$ ではサ行 5 音全てが $4,500 \mathrm{~Hz}, \mathrm{D}(4,6)$ ではサ行 5 音全てが 5,000 $\mathrm{Hz}$ であり，どの実験用義茵においても被験語間の差は 小さかった。 また, サ行 5 音の強調点の周波数の平均を 各実験用義歯でとで比較すると， $\mathrm{D}(2,2)$ では $5,500 \mathrm{~Hz}$ ， $\mathrm{D}(2,4)$ では, $5,200 \mathrm{~Hz}, \mathrm{D}(2,6)$ では, $4,500 \mathrm{~Hz}, \mathrm{D}$ (2,6) では, $5,000 \mathrm{~Hz}$ であり, オーバージェットの増加 にともない強調点は下降傾向を示した．しかしD $(4,6)$ で示すようにオーバージェットを $4 \mathrm{~mm}$ 増加させオーバ 一バイトが $2 \mathrm{~mm}$ 増加させた場合は，強調点の下降傾向 は減少した。

各実験用義蒾ごとの強調点のエネルギーレベルを各被 験語別に表14に示した。強調点のエネルギーレベルはD 
表14 強調点のエネルギーレベル

\begin{tabular}{|c|c|c|c|c|c|c|}
\hline 実験用義搻 & サ & シ & ス & セ & ソ & 平均値 \\
\hline $\mathrm{D}(2,2)$ & $14 \cdot 1$ & 20.1 & 20.9 & 18.0 & 17.7 & 18.2 \\
\hline $\mathrm{D}(2,4)$ & 12.1 & 18.5 & 17.7 & 15.5 & $14 \cdot 9$ & 15.7 \\
\hline $\mathrm{D}(2,6)$ & 10.2 & 15.3 & $15 \cdot 9$ & $14 \cdot 3$ & 13.5 & 13.8 \\
\hline $\mathrm{D}(4,6)$ & 13.0 & 18.9 & 21.8 & 16.4 & 16.0 & 17.2 \\
\hline
\end{tabular}

$(2,2)$ では最大のものがス音 $(20.9 \mathrm{~dB})$, 最小のものが サ音 $(14.1 \mathrm{~dB}), \mathrm{D}(2,4)$ では最大のものがシ音 (18.5 $\mathrm{dB})$, 最小のものがサ音 $(12.1 \mathrm{~dB}), \mathrm{D}(2,6)$ では最大 のものがス音 $(15.9 \mathrm{~dB})$ ，最小のものがサ音 $(10.2 \mathrm{~dB})$, $\mathrm{D}(4,6)$ では最大のものがス音 $(21.8 \mathrm{~dB})$ ，最小のもの がサ音 $(13.0 \mathrm{~dB})$ であった. どの実験用義眯において も強調点のエネルギーレベルはシ音およびス音が大き く, サ音が最も小さかった。 またサ行 5 音の強調点のエ ネルギーレベルの平均を実験用義茵でとに比較すると, $\mathrm{D}(2,2)$ では18.2dB， D $(2,4)$ では $15.7 \mathrm{~dB}, \mathrm{D}(2,6)$ では $13.8 \mathrm{~dB}, \mathrm{D}(4,6)$ では17.2dBでありオーバージ. ットの増加にともない, 強調点のエネルギーレベルは低 下傾向を示した。しかし，D(4,6) で示すようにオーバ ージェットを $4 \mathrm{~mm}$ 増加させオーバーバイトを $2 \mathrm{~mm}$ 増 加させた場合は，強調点のエネルギーレベルの低下傾向 は減少した。

\section{III. 各実験項目間の単相関分析}

各実験項目において, $\mathrm{D}(2,2) \cdot \mathrm{D}(2,4)$ 間, $\mathrm{D}(2,2)$ - $\mathrm{D}(2,6)$ 問, $\mathrm{D}(2,2) \cdot \mathrm{D}(4,6)$ 間で平均值の差の検 定を行い，有意差があった被験語数を各被験者ごとに求 め表 $3 ， 6 ， 9 ， 12$ に示したが，乙の被験者ごとで有意 差があった被験語数を変量として, 各実験項目間の単相 関分析を行った。上下的 $\mathrm{S}$ 発音位と前後的 $\mathrm{S}$ 発音位の 間，上下的 $\mathrm{S}$ 発音位と子音継続時間の間，上下的 $\mathrm{S}$ 発音 位と平均振幅の間，前後的 $\mathrm{S}$ 発音位と子音継続時間の 間，子音継続時間と平均振幅の間には，どの実験用義蒾 の対応関係においても，有意の相関は認められなかっ た。しかし, 前後的 S発音位と平均振幅の間では，D $(2,2) \cdot \mathrm{D}(2,6)$ 間の相関係数は 0.37 であり，危険率 1 \%で有意に正の相関が認められた，その散布図および回 㷌直線を図 7 に示した。また D $(2,2) \cdot \mathrm{D}(4,6)$ 間の相 関係数は 0.32 であり，危険率 $5 \%$ で有意に正の相関が認 められた。その散布図および回帰直線を図8 亿示した.

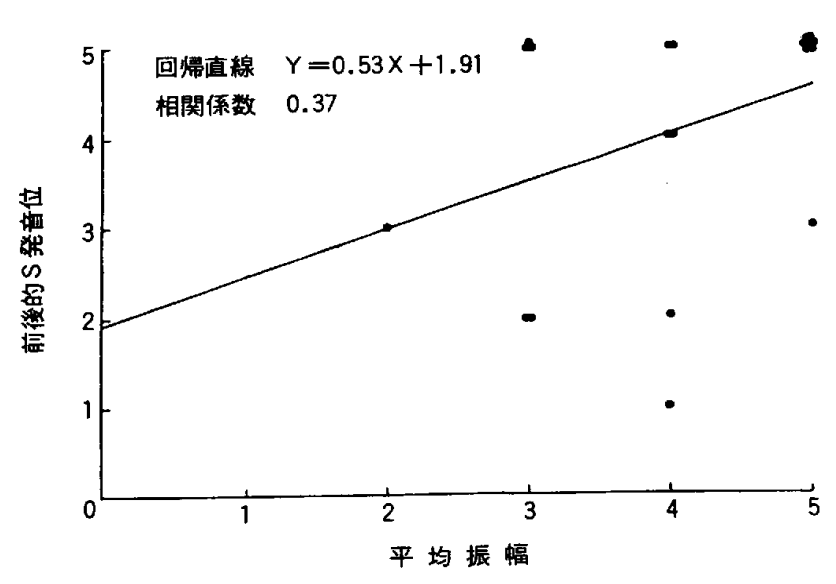

$\mathrm{D}(2,2) \cdot \mathrm{D}(2,6)$ 間で平均值の差の検定を 行い有意美があった被験語数を各被験者ごとに 求め変量とした。

図 7 前後的 $\mathrm{S}$ 発音位と平均振幅の相関図

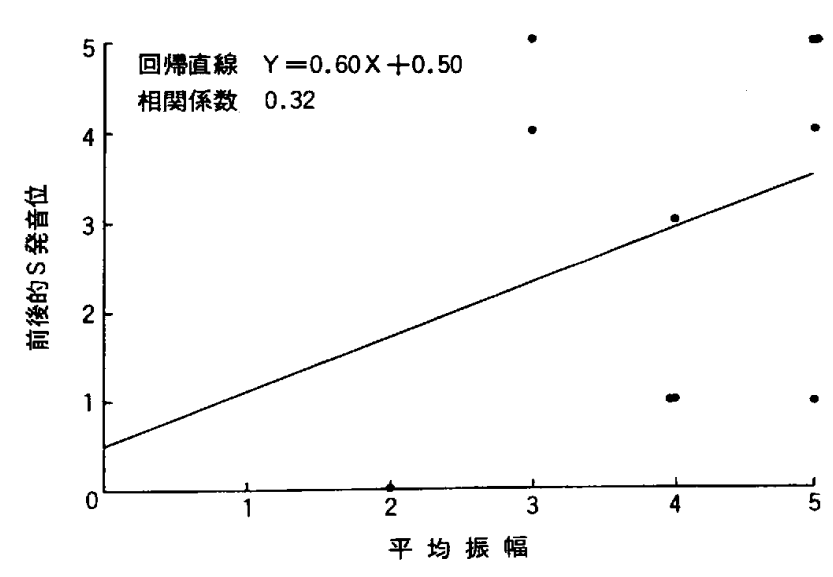

$\mathrm{D}(2,2) \cdot \mathrm{D}(4,6)$ 間で平均值の差の検定を 行い有意差があった被験語数を各被験者ごとに 求め変量とした。

図 8 前後的 $S$ 発音位と平均振幅の相関図

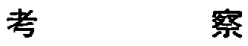

補経臨休において発音と前歯部排列位置との関係は従 来より重要視されており，前歯部排列位置が調音運動と 調和しない場合は種々の発音障害を引き起こすことが知 られている，特に発音障害は摩擦音である $\mathrm{S}$ 音で著明で あり，発音明瞭度の低下や誤聴傾向の増加などが報告さ れている14,15,20,32,36)。そこで本実娩でも最も影響 を受けやすいS音を対象とし，比較的自然に近い調音運 動が可能なサ行 5 音の連続音節を被験語とした。

また，一般にS音は上顎前歯舌側面と舌尖が調音点と なり形成されるため，上䫟前歯の排列位置が問題とされ る.したがって無雨顎者を対象とし上顎前米の排列位置 
を変えた実験用義茵を作製し発音への影響を検討した Ariffin (1982 ${ }^{36)}$ の報告や, 左右の上顎中切歯が久損 している被験者を対象に実験用ポンティクを作製し，前 雷被蓋度の変化が発羙機能に及ぼす変化を観察した田中 (1986) $^{15)}$ の報告などのように，上顎前菊部の排列位置 を扱ったものは多いが，下顎前歯の排列位置に関する報 告は少ない。しかし下顎前茵部をあまり舌側に排列しす ぎると，舌の運動範囲が狭まり舌の調音運動に障害をき たすおそれが十分あり，下顎前歯の排列位置と発音との 関係を検索することは非常に重要である．そこで本実験 では下顎前歯部を含む久損症例に対してオーバージェッ おトよびオーバーバイトを変化させた 4 種類の実験用義 柬を作製し， M. K. G. による S 発音位の分析およびサ ウンドスペクトログラフによる音声の分析を行い，下穎 前雬部排列位置の変化が発音に及ぼす影響を詳細に検討 した。

\section{S 発音位}

Silverman $(1951,1956)^{37,38)}$ はS 発音時に下顎は 上顎に最も接近するととから，ての䫇位と中心咬合位と の垂直距離を closest speaking space と呼んだ. こ れは個人差が大きいが同一個人では生涯不変のものであ るので, 有菌顎時に closest speaking space を記録 しておき，義粜作製時の咬合高径の決定に利用する方法 を提唱した。またPound (1966，1971) 39，40) はS音発 音時の下顎の位置を $\mathrm{S}$ 発音位と呼び， $\mathrm{S}$ 発音位は比較的 再現性に富む安定した顎位であることから，乙れを利用 して発音時の下顎運動に調和するように下顎前歯を排列 し, さらにての被蓋関係を基準として咬合高径を求める 術式を確立した。

しかし日本語の場合, $\mathrm{S}$ 音は単独で発音されることは なく，常に舟音と結合した形で発音されるので一定の顎 位を持続することはい，乙のような特徵を持つ日本語の S発音位に関して, 田中 $(1980)^{21}$ ' は有米顎者を対象と して，また桜井 $(1980)^{12}{ }^{2}$, 车田ら (1982) ${ }^{23}$ ) は無雨顎 者を対象として詳細な検討を行っている。

本実験では，下顎前歯部が欠損している被験者に対し て 4 種類の実験用義料を作製し，それらの義类を装着し てサ行音を発音させ， $S$ 発音位について検討した。その 結果, オーバージェットを $2 \mathrm{~mm}$, オーバーバイトを 2 $\mathrm{mm}$ とした標準型実験用義歯 $\mathrm{D}(2,2)$ では，どのサ行音 においても前後的 $\mathrm{S}$ 発音位の位置的変化はないてとがわ かった，一方上下的 S発音位には被験語間に差が認めら れた。すなわち，サ，シ，ス，セの 4 音の上下的 $\mathrm{S}$ 発音 位は近似していたが，ソ音のS 発音位は他の被験音と比
較して最も下方に位置していた．また前後的S発音位に しろ上下的 $\mathrm{S}$ 発音位にしろ全被験者を対象とすると標準 偏差は大きな值であり個人差が大きかったが，同一個人 の同一被験語に限れば $\mathrm{S}$ 発音位は比較的再現性の高い安 定した顎位であった（表 1 ）.

一般に摩擦音である $\mathrm{S}$ 音は，舌の側方部が小臼歯部お よび大四菌部に接触し, 舌尖が上顎前雪舌側面付近に位 置することにより, 形成された幅の狭い前後に長いトン ネル状の通路を通った呼気が，前荬に吹き付けられて生 じる．乙のS音を形成するための調音運動は $0.1 \sim 0.2$ 秒 程度の瞬間的なものであり，即座に後続母音のための調 音運動に移行しなければならない，本実験ではサ行 5 音 の連続音を被験音として用いたため，比較的開口量の大 きい隣接母音を持つソ音で closest speaking space が 最も大きく，後続母音および先行する隣接母音の調音運 動の影響を受けたものと思われる．すなわち，隣接母音 発音時の下顎位, 舌の位置, 口唇の位置などが $\mathrm{S}$ 発音位 に微妙に影響を及ぼしたのではないかと推察される。こ れは $\mathrm{M} \cdot \mathrm{K} \cdot \mathrm{G}$.を使用して $\mathrm{S}$ 音発音時の下顎の連続的な 運動を観察し, サ行の $\mathrm{S}$ 発音位は特に後続母音の影響を 大きく受けると述べている田中 $(1980)^{211}$ の報告と一致 した.

また， $\mathrm{S}$ 発音位は個人差が大きく，特に上下的 $\mathrm{S}$ 発音 位に扔いては被験語間の差も梕められたが，同一個人の 同一被験語に限っていえば， $\mathrm{S}$ 発音位のばらつきは非常 に小さく $\mathrm{S}$ 発音位は比較的再現性の高い下顎位であっ た。したがって発音条件を一定にすれば安定した下顎位 を十分再現することができ，咬合高径を決定する方法と して利用価值が高いと思われる。

しかし，同一の発音条件でも口腔内環境が変化すれば $\mathrm{S}$ 発音位も変わる，车田ら $(1982)^{23}{ }^{3}$ は全部床義䨑装着 時と非装着時では明らかにS 発音位は異なり，有歯顎時 代の習慣的な下顎位が雨牙欠損後にも再現されるととは 期待すべきではないと述べている．桜井（1980）121 は正 常有雨颚者を対象として全口蓋床が $\mathrm{S}$ 発音位に及ぼす影 響を検討し，全口蓋床の厚径の増加にともなって開口量 は有意に増加すると報告している．また前蒾部被害度と $\mathrm{S}$ 発音位との関係について，立石 $(1978)^{201}$ は正常有柬 顎者の咬合高径を増加させることにより前歯の被蓋度を 変化させ, $\mathrm{S}$ 音発音時の上下前歯の位置関係を分析し, $\mathrm{S}$ 音発音時の下枵前歯の移動量は被験者によって異なっ ており，しかも被蓋度との直接的関連もみられなかった と述べている．さらに田中 $(1986)^{15)}$ は左右の上顎中切 柬が久損している被験者を対象にして水平被蓋を変化さ 
せ, S 音発音時の下頂切茵点の運動を $\mathrm{M} \cdot \mathrm{K} \cdot \mathrm{G} \cdot$ でとら え, $\mathrm{S}$ 発音位は個人差が大きく被蓋度と $\mathrm{S}$ 発音位に一定 の相関関係は認められなかったと報告している。

本実験では下顎前歯部を含む欠損症例を対象としてオ ーバーシェェット，オーバーバイトを変化させた 4 種類の 実験用義菌を作製し，下䫇前歯部の排列位置の変化が $\mathrm{S}$ 発音位に及ぼす影響について詳細に検討した，D $(2,2)$ を基準とし, $\mathrm{D}(2,2) \cdot \mathrm{D}(2,4)$ 間, $\mathrm{D}(2,2) \cdot \mathrm{D}(2,6)$ 間, $\mathrm{D}(2,2) \cdot \mathrm{D}(4,6)$ 間に扔いて上下的 $\mathrm{S}$ 発音位に関 する平均值の差の検定を行ったとてろ，全被験語数に対 して有意差があった被験語数が示す割合は，それぞれ $14 ， 38 ， 50 \%$ であたが，変位を示した上下的 $\mathrm{S}$ 発音位 の移動方向には一定のパターンはみられなかった（表 $2)$. 前後的 S発音位に関しては，全被験語数に対して 有意差があった被駼語数の示す割合は，それぞれ 34 , $81,58 \%$ であり，オーバージェットの増加による影響 は，上下的 S発音位よりも前後的 S 発音位の方に顕著に 認められた（表 5 )。またオーバージェットの増加によ る影響を受けて前後的 S発音位は前方移動傾向を示した が，D $(4,6)$ の上うにオーバージェットを $4 \mathrm{~mm}$ 増加さ せオーバーバイトを $2 \mathrm{~mm}$ 増加させた場合は, 前後的 $\mathrm{S}$ 発音位の前方移動傾向は減少した（表 4, 表 5)。

摩擦音は上颓前菌舌面と舌の間に狭めを形成し呼気を 前蒾にに吹き付けることによって生じるが，下颗排列 位置を変えてオーバージェットを增加させると調音点は 後方に下がり, 舌の摩擦音形成のための調音運動は大き く障害を受ける. 音の変化が聴覚で感知されるとただち にフィードバック機構が働き，調音運動の調整が行われ る。一般に摩擦音の主な調音運動は舌によるるのであ り，下顎は従的役割をしておら，補正的な調音運動は最 も運動に富む舌の担うとてろが大きく，下顎は舌が適切 な調音運動を行う際の補助的な役割をすると思われる。 本実験に扔いてオーバージェットの増加にともない前後 的 S 発音位は前方に移動する傾向を示したが，前後的 S 発音位の前方移動量は増大した上下顈前菌間の間隙を補 償できるほどのものではなかったのであろう，またオー バージェットの増加が上下的 S 発音位に及济す影響は比 較的小さく，変位を示した上下的 S 発音位にも一定の傾 向は認められず, 田中 $(1986)^{151}$, 古屋 (1971) ${ }^{221}$ らの 水平被蓋が大きくなると上下的な下顎位のばらつきも大 きくなるという報告とも一致した。

$\mathrm{D}(4,6)$ のようにオーバージェットを $4 \mathrm{~mm}$ 増加させ オーバージェットを $2 \mathrm{~mm}$ 增加させた場合は, オーバー ジェットのみを $4 \mathrm{~mm}$ 増加させた D $(2,6)$ と比較する
と, 前後的 $\mathrm{S}$ 発音位の前方移動䝨向はやや減少してお り，オーバーバイトの増加に: り舌の補正的調音運動の 負担が減り，口蓋と舌による荻めの形成が容易になった とも推察できる。しかし本実験のような失状面に打ける $\mathrm{S}$ 発音位の観察結果だけでは結論は得られず，パラトグ ラフ，リンゴグラフ，X線などにより舌の動態を観察 し，舌と下顎の相互関係を検討する必要があろう。

II . 子音継続時間

子音継続時間は同一個人においても常に一定ではなく 発音条件によって変化する. 子音継続時間を左右する要 因としては，声の大小，発音の速さなどが挙げられるが， 単音か連続音かというととも重要な要因であり, 単音で 発音する場合は単文などの連続音で発音する場合により 子音継続時間が延長することは周知の事実である，さら に連続音節を発音する場合は隣接する母音の影響も考慮 しなければならない。

本実験ではサ行音を連続して発音させ各サ行音の分析 をしたが，その結果オーバージェット $2 \mathrm{~mm}$ ，オーバー バイト $2 \mathrm{~mm}$ である標準型実験用義䨑 $\mathrm{D}(2,2)$ において 子音継続時間が最も長かったのはシ音（145士33msec）, つでス音 $(142 \pm 27 \mathrm{msec})$, 七音 $(140 \pm 33 \mathrm{msec})$, ソ

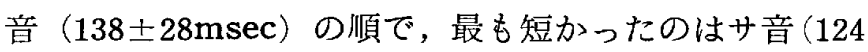
$\pm 27 \mathrm{msec}$ ) であった（表 7)。乙れは桐谷 $(1978)^{411}$ が 連続音節発音時の先行子音発音時間は後続母音の影響が 大きいと述べているように，後続母音の開口量の違いに よるものと思われる.すなわち後続母音の開口量が最も 小さいシ音で子音継続時間は最も長く, 後続母音の開口 量が最も大きいサ音で最も短かった。このことは, サの ように開口位のSから大開き母音のaに連なる場合は舌 の運動範囲が大きく摩擦音の持続は短くなるが，逆に ス, シでは先行子音之後続母音 (小開き母音) の調音運 動の差が少ないため，摩擦音が比較的長く持続するとい う山縣（1964）421の報告ともほぼ一致しだ。

また発音条件の変化だけでなく，口腔内環境が変化し ても子音継続時間は影響を受ける可能性がある.しかし 下顎前菌部の排列位置を変え被蓋度を変化させて子音継 続時間への影響をみた本実験においては，表 8 で示すよ うに全被験語数に対して有意差があった被験語数が示す 割合は $\mathrm{D}(2,2) \cdot \mathrm{D}(2,4)$ 間で15\%，D $(2,2) \cdot \mathrm{D}(2,6)$ 間で $13 \% ， \mathrm{D}(2,2) \cdot \mathrm{D}(4,6)$ 間で $22 \%$ 被験者を除けばどの実験用義歯の刘応関係においても特 異な傾向は認められず，下顎前菌部の排列位置が子音継 続時間に及ぼす影響は小さかった。一般に義菌を装着し ない場合や前菡が多数欠損した場合のような劣悪な口腔 
内環境において調音運動が著しく阻害されると，子音継 続時間に影響が出ることが知られているが，本実験のよ うに下顎前歯部の排列位置を変化させた場合は，子音継 続時間を乱すほど調音運動を阻害するわけではなく，被 験者のフィードバック機能の働きで比較的適切な発音が できるのではないかと推察される.

\section{III. 平均振幅}

摩擦音は口蓋と舌によって形成された狭い通路を気流 が摩摖しながら流れて発生する持続的な雑音であり，平 均振幅はこの音压エネルギーを相対的に示すものであ る. オーバージェット $2 \mathrm{~mm}$ ，オーバーバイト $2 \mathrm{~mm}$ ある標準型実験用義菌 $\mathrm{D}(2,2)$ では，平均振幅は明らか に被験語間に差があり，シ音抢よびス音が大きくサ音が 最も小さかった（表10）．前述の子音継続時間の分析に おいて, シ音およびス音の子音継続時間は比較的長く, サ音の子音継続時間は最も短かったが，ての子音継続時 間が平均振幅の大きさを決定する一要因であると推測さ れる.つまり子音継続時間が長いシ音およびス音では, 口蓋と舌によって形成された狭めが持続する時間が長 く，そてを通過する呼気の総量が大きくなり，必然的に 音压エネルギーが增大し相対的に平均振幅が大きくなる のに対し，逆に子音継続時間が短いサ音では，狭めが形 成される時間が短く，通過する呼気の総量が小さくなる ので平均振幅も小さくなったと思われる.

下顎前菌部の排列位置の変化が平均振幅に及ぼす影響 について被験語間, 被験者間で詳細な検討を行った結 果, 表10, 表11からわかるようにオーバージェットの増 加にともない平均振幅は減少傾向を示した．有意差があ った被験語数が示す割合は, $\mathrm{D}(2,2) \cdot \mathrm{D}(2,4)$ 間では $50 \%$ あったが， $\mathrm{D}(2,2) \cdot \mathrm{D}(2,6)$ 間では $81 \%$ あ゙あり， またほとんどの被験者においてオーバージェットが増加 した影響が顕著に認められた（表12）。

てれはオーバージェットの増加により阻害された通常 のS 音発生機構に対する調音器官の代償的調音運動が， 完全ではないととを示している。すなおちオーバージェ ットの増加により下頭前雨が相対的に上顎前歯より後退 するので，それにつれて舌が後退を強いられ，呼気が放 出される部位である調音点も後退するので, 口蓋と舌に よる狭めの形成が困難になったものと思われる，また通 常のS音は，上顎舌側面と舌尖より放出された気流が上 頢前楝に吹き付けられることにより一層摩擦音としての 性質を強めるが，調音点が後退すると狭めを通過した気 流が自由に放出されるために，平均振幅は小さくなった とも考えられる.また表10より平均振幅の平均值を実験
用義歯ごとにみると， D $(2,2)$ は $95.2 \% ， \mathrm{D}(2,4)$ は $84.1 \%, \mathrm{D}(2,6)$ は72.0\%であり,オーバージェットの 増加にともない平均振幅は減少したが，オーバーバイト を $2 \mathrm{~mm}$ 増加させた D $(4,6)$ は84.0\%であり，D $(2,6)$ と比較すると平均振幅はやや増加した。つまりオーバー ジェットを増加させると平均振幅に影響が泾められる が，オーバージェットを増加させてもオーバーバイトを 同時に増加させると, 舌の補正的調音運動の負担が軽く なり狭めの形成が容易になり、平均振幅への影響が減少 したものと考えられる。

IV. 周波数分析

サウンドスペクトログラフによる周波数分析は時間軸 上の特定の時点の周波数とエネルギーレベルの関係を二 次元的に分析するものであるが，一般に周波数分析を行 った実験では强調点のエネルギーレベルを測定したもの が多い.しかしサウンドスペクトログラム上の強調点は 1つとは限らず，同程度のエネルギーレベルを示す周波 数がいくつか存在するてとも多く．強調点の測定が困難 な場合も多々ある，そてで本実験では 0 汃ら $10,000 \mathrm{~Hz}$ まで $500 \mathrm{~Hz}$ ごとに各周波数成分におけるそれぞれのエネ ルギーレベルを測定し， 5 回の被験音の平均を求め, そ の值が最大である周波数を強調点の周波数とした．その 結果，強調点だけでなく全周波数域においててもエネル ギーレベルの比較が可能になった. 周波数分析の結果, オーバージェットの増加にともない，サ行 5 音全てにお いて 4,500 $5,000 \mathrm{~Hz}$ から 9,500 10,000Hz までの高周 波数域でェネルギーレベルは低下傾向を示した（図 2 図6).また同様に強調点のエネルギーレベルもオーバ ージェットの増加にともない低下傾向を示した（表13）. オーバージェットの増加にともないエネルギーレベルが 低下したのは（表14），平均振幅の項で述べたように補 正的調音運動が完全ではないてとが原因と思われるが， 特定の周波数域のエネルギーレベルのみが低下するので はなく，4,500〜5,000Hzから 9,500〜10,000Hzまでの 比較的広い周波数域のどの周波数においてもエネルギー レベルは同程度低下することがわかった．てのように比 較的高周波数域でエネルギーレベルが減少したてとにつ いては，口蓋と舌で形成される狭めの形態が関係してい るものと思われる。っまり音の音響学的特徽として気流 が横切る管状の通路が狭ければ狭いほど高周波数域のエ ネルギーレベルが大きくなるととが知られており ${ }^{43}$ ， 舌の補正的調音運動によって形成された狭めは通常の狭 めより広いことが推測される. またD $(4,6)$ の周波数分 析の結果, サ行 5 音全てにおいてェネルギーレベルの低 
下傾向は減少し，同様に強調点のエネルギーレベルも少 した.さらに強調点の周波数の低下傾向も減少してお り，D $(4,6)$ の場合はエネルギーレベルが比較的回復す るととがわかった（図 2〜図6，表13，14）。つまり才 ーバージェットを $4 \mathrm{~mm}$ 増加させオーバーバイトを 2 $\mathrm{mm}$ 増加させた場合は, 舌の補正的調運動の負担が軽く なり，比較的正常な狭めの形成ができたということが間 接的に想像される。

\section{$V$ ．各実験項目間の関係について}

各実験項目間の単相関分析を行った結果，変量が前後 的 $\mathrm{S}$ 発音位，平均振幅である場合の $\mathrm{D}(2,2) \cdot \mathrm{D}(2,6)$ 間抢よび $\mathrm{D}(2,2) \cdot \mathrm{D}(2,4)$ 間に有意に正の相関関係が 認められた。（図 7，8）てれは，S発音位の項で述べ たように聴覚がエネルギーレベルの低下を知覚し,フィ 一ドバック機構が作動した結果, 補正的調音運動の一環 として前後的 $S$ 発音位にも影響が及ぶてとを毫付けるも のである。

以上の考察により総合的に結論すると，下䫇前菌部の 排列位置を変え才ーバーシェットを増加させた場合は明 らかにS 音形成に悪影響が認められ，特にエネルギーレ ベルの減少傾向が影著であった，またオーバージェット を増加させてもオーバーバイトを同時に増加させた場合 は，エネルギーレベルの減少傾向は低下した。すなわち 人工㐘を排列する場合は発音を考慮して下䫚前茵部の排 列位置に十分留意する必要がある。

\section{結 論}

発音機能において下頡前蒾部の排列位置が果たす役割 は大きく，下顎前蒾部の排列位置と発音との関係を検討 することは非常に重要なととである．そこで本実験では 下顎前歯部を含む欠損症例に対してオーバージェット， オーバーバイトを変化させた 4 種類の実験用義茵を作製 し，M.K.G.による S 発音位の分析およびサウンドス ペクトログラフによる音声の分析を行い，下䫟前歯部排 列位置の変化が発音に及ぼす影響を詳細に検討したとこ ろ, 以下の結果を得た。

1. オーバージェット $2 \mathrm{~mm}$ ，オーバーバイト $2 \mathrm{~mm}$ とした標準型実験用義蒾では，全てのサ行音において前
後的 $S$ 発音位に位置的変化はなかった。

2. 一方上下的 $\mathrm{S}$ 発音位は被験語間に差が認められ， サ，シ，ス，七の 4 音は近似していたが，ソ音は他の被 験者と比較して最も下方にあった。

3. オーバージェットの増加が前後的 $\mathrm{S}$ 発音位に及ほ す影響は比較的大きく, 前後的 S 発音位は前方移動傾向 を示した．しかしオーバージェット $6 \mathrm{~mm}$ ，オーパーバ イト $4 \mathrm{~mm}$ とした実験用義菡では, 前後的 $\mathrm{S}$ 発音位の前 方移動傾向は減少した。

4.オーバージェットの増加が上下的 $\mathrm{S}$ 発音位に及ぼ す影響は比較的小さく，上下的 S 発音位の移動方向にも 一定のパターンはみられなかった。

5. 子音継続時間は被験語間に差が諗められ，シ音お よびス音が比較的長くサ音が最も短かった。

6. 下顎前菌部の排列位置が子音継続時問に及ぼす影 響は小さかった。

7. 平均振幅は被験語間に差が認められ，シ音および ス音が比較的大きくサ音が最も小さかった。

8. オーバージェットの増加が平均振幅に及ぼす影響 は顕著であり, 平均振幅は減少傾向を示したが, オーバ ージェット $6 \mathrm{~mm}$ ，オーバーバイト $4 \mathrm{~mm}$ とした実験用 義茵では減少率は低下した。

9. 周波数分析の結果, オーバージェットの増加にと もない，サ行 5 音全てに拀いて $4,500 〜 5,000 \mathrm{~Hz}$ から 9,500 $10,000 \mathrm{~Hz}$ までの高周波数域でエネルギーレベル は低下傾向を示した．しかしオーバージェット $6 \mathrm{~mm}$ ， オーバーバイト $4 \mathrm{~mm}$ とした実験用義歯ではエネルギー レベルの低下傾向は減少した.

稿を終わるにあたり, 本研究に終始御懇篤な御指導と 御校閲を賜わった恩師豊田静夫教授に対し，深甚なる感 謝の意を表すとともに，数多くの御援助，御助言をいた だいた九州歯科大学歯科補緅学第 2 講座内田康也教授, 九州歯科大学生理学教室中原敏教授, ならびに本教室三 宅茂樹講師に亚心より謝意を捧げます。

また本研究に御協力いただきました補経学教室の皆様 ならびに被験者の方々に心から感謝致します。

\section{引用 文 献}

1）松本教夫：全部床義歯患者の発音の研究（その1）自覚障害について．口病誌 $38 ： 252-265 ， 1971$.

2）奥田貫之：実験的局部口蓋床の発音に及ぼす影響. 補緅誌 $16: 362-380,1972$.

3）桑原 勉：義歯口蓋形態が音声に及ほすす影響について．岐歯学誌 $9 ； 231-247 ， 1981$ ， 
4 ) 清水健吾：日本語子音の発語明瞭度とソナグラム， 口病誌 $38: 496-517,1971$.

5 ）積田正和：咬合高径の変化がパラトグラムと発音明瞭度に及ぼす影響。補綴誌 $27 ： 1$ - $19,1983$.

6 ）山縣健佑・森田啓一・松本教夫・清水健吾・古屋紀一：補綴処置の発音に及ぼす影響について 第 3 報 口 蓋板により発音を回復した一症例。補経誌 $13: 193-203 ， 1969$.

7 ) 吉川 弥：全口蓋休が破裂音構成に及ぼす影響。粜科医学 28：167-206，1965.

8 ）園田秀明：発音明膫度とパラトグラム。補経誌 $20: 633-650,1976$.

9) Goyal, B.K. : Functional contouring of fhe palatal vault for improvimg speech with complete dentures, J. Prosthet. Dent. $48: 640-646,1982$.

10) Palmer, J.M. : Analysis of speech in prothodontic practice, J. Prosthet. Dent. 31:605-614, 1974 .

11）市川哲雄：S 発音時の舌の動態に関する研究。補経壳 $31: 740-752,1987$.

12）桜井克守：サ行調音時の下顎運動の実験的研究一全口盍床の影響について一。補綴誌 24:486一-496, 1980 .

13）佐藤修斎：発音のメカニズムに関する研究 第 2 報 全部床義畨装着者. 補経誌 $31: 389-402,1987$.

14）田中収・山㝥健佑・坂口邦彦：前歯部完全自浄型ポンティックが発音機能に及ぼす影響。補緅誌 30： $169-178,1986$.

15）田中収・高相利次・山楽健佑・坂口邦彦：前㐘部被蓋度の変化が発音機能に及ぼす影響. 補経誌 30 ： $1114-1121,1986$.

16) Harley, W.T. : Dynamic palatography-A study of linguopalatal contact during the production of selected consonant sound, J. Prosthet. Dent. $27: 364-376,1970$.

17) Allen, L.R. : Improved phonetics in denture construction, J. Prosthet. Dent. 19:753-753, 1958 .

18）森田啓一・安部修平・矢島洋子・関 秀孝・山本幸雄：構音からみた口蓋形熊について. 補綴誌 12 ：115 $-125,1986$.

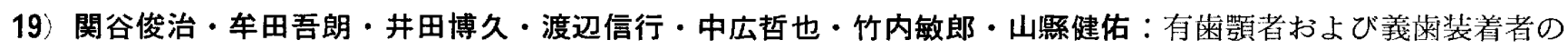
発曋時の下顎運動。補緅誌 $24: 689-702,1980$.

20）立岩達治：前歯部被蓋度と発音との関係. 補経誌 $22: 113-134,1978$.

21）田中収：日本語 $\mathrm{S}$ 発音時の下顎運動に関する研究. 補経誌 $24: 628 一 645 ， 1980$.

22）古屋紀一：X線映画法による発音時の下顎位に関する研究。補緅誌 $15: 221$-236, 1971 .

23）军田吾朗・関谷俊治・戸高勝之・高林成日己・土田 裕・清水玲子・竹内敏郎・積田正和・山縣健佑：義茵 装着時下顎運動に関する研究. 補緅誌 $26: 697-709,1982$.

24）山楽健佑・高林成日己・土田 裕・清水玲子・関谷俊治・竹内敏郎・積田正和・田中 収：義䨑の咬合高径 の変化が発音時下顎位に及ぼす影響。補緅誌 $26: 1108-1117,1982$.

25) Chaney, S.A. Moller, K.T. and Goodkind, R.J. : Effect of immediate dentures on certain structural and perceptual parameters of speech, J. Prosthet. Dent. $40: 8-13,1978$.

26）金本安敏: Sona Graph について. 耳鼻咽侯科臨床 $49: 785-790,1956$.

27）釜本安敏：日本語母音特性の Sona Graph による研究. 耳鼻咽诶科臨休 $50: 28-35,1957$.

28）河辺清治：口蓋桿の調望に及ぼす影響につい（その1）。菌科学報 59：1-7，1959.

29）河辺清治：口蓋桿の調音に及ぼす影響につい（完）。粜科学報５9：95-99，1959.

30）小塩博司：全口蓋床を基準として床設計への適応性に関する音響学的考察. 補経誌 $29: 560$ 一 $575 ， 1985$.

31) 小林 豊：ソナグラフ Sona-Graph. 日本音響学会杂倠誌 11:57一64, 1955.

32）櫻井和人・荒井賢一・吉沢典男：Sona-graph による発音の研究 第 4 報 総義歯|に求ける前歯部欠損並 びに移動による発音の変化特にサ行について．歯科学報 $58: 1-4,1958$.

33）佐藤利男：日本語子音の周波数スペクトル。学士院紀要 $14: 113-121,1956$.

34）友松英美：義歯の発音に及ぼす影響に就いて。歯科学報 $31: 295-330 ， 1959$. 
35）山縣健佑・松本教夫・森田啓一・高橋 衛：補緅処置の発音に及ぼす影響について 第 2 報 前蒾部の補緅 例. 補緅誌 $10: 205-213,1966$.

36) Ariffin, Y.T. : Sonagraphic analysis of speech sounds with varying positions of the upper anterior teeth, J. Dentistry. $10: 17-27,1982$.

37) Silverman, M.M. : Accurate measurement of vertical dimension by phonetics and the speaking centric space, Dent. Digest. $57: 261-265,308-311,1951$.

38) Silverman, M.M. : Determination of vertical dimension by phonetics. J. Prosthet. Dent. 6 : $465-471,1956$.

39) Pound, E. : The mandibular movements of speech and their seven related values, J. Prosthet. Dent. $16: 835-843,1966$.

40) Pound, E. : An introduction to denture simplification, J. Prosthet. Dent. 26:570-581, 1971.

41）桐谷 滋：日本語母音. 子音調音の隣接音の影響による変動. 日本音響学会誌 $34: 132-139,1978$.

42）山縣健佑：発音試験用標準日本語彙に関する研究。補緅誌 8：173-217，1964。

43) Schubiger，M. 小泉 保訳：新版音声学入門. 大修館65，1985. 